\title{
大型振動台実験に基づく液状化過程での杭の水平地盤反力変位関係のモデル化 MODELING OF HORIZONTAL SUBGRADE REACTION OF PILE DURING SOIL LIQUEFACTION BASED ON LARGE SHAKING TABLE TESTS
}

\author{
時 松 孝次*, 鈴木 比呂子**, 佐伯 英一郎*** \\ Kohji TOKIMATSU, Hiroko SUZUKI and Eiichirou SAEKI
}

\begin{abstract}
The coefficient of subgrade reaction of pile during soil liquefaction is back-calculated based on large shaking table tests. The effects of soil density, relative displacement and pore water pressure ratio on the $p-y$ relation between subgrade reaction and relative displacement are examined, and a simplified procedure to estimate time history of $p-y$ relation is presented. The $p-y$ relations computed by the proposed method are in good agreement with the experimental ones, irrespective of depth, level of input motion and soil density, indicating that the proposed method is promising for estimating p-y relations during soil liquefaction.
\end{abstract}

Keywords: Shaking table test, Liquefaction, Pile, Subgrade reaction, Relative Displacement, Pore water pressure 振動台実験, 液状化, 杭基礎, 地盤反力, 相対変位, 間隙水圧

1. はじめに

1995 年兵庫県南部地震をはじめとする近年の地震では, 液状化 地盤の変形による杭基礎被害が多数報告されている.このような地 盤変形に起因する杭応力を推定するには, 地表から地中部までの地 盤変形に加え, 杭の水平地盤反力変位関係を適切に評価することが 重要である，しかし，液状化時の地盤反力变位関倸を精度良く得る ことは難しく，これを実測した研究や，実測にもとづいて地盤反力 変位関係のモデル化を試みた研究はほとんど見あたらない。

1999 年に(現独立行政法人)防災科学技術研究所では, 各哚度の地 盤反力变位関係を精度良く得ることを目的に，ひずみゲージおよび センサーを深度方向に多数配置して, 地盤-杭-構造物系の大型振動 台実験 "が行われている，前報 2)では，その実験結果にもとづき， 杭の水平地盤反力, 杭之地盤の相対変位の時刻歴を求め, 地盤反力 変位関係に影響を与える要因について検討している，本報では，笑 験結果と前報にもとづいて，各要因の影響を定量的に評価するとと もに，地盤反力変位関係をモデル化し，その有効性を検討する。

\section{2. 大型土槽の振動実験から求めた地盤反力係数の支配要因}

\section{1 実験概要と杭の水平地盤反力変位関係の推定}

振動実験 ${ }^{122}$ は，表 1 に示すように，基礎の根入れの有無，上部 構造物の有無とその固有周期をバラメータとした計 6 ケースの地盤 一杭-粠造物系に対し，入力地震動の振幅を段階的に大きくして行わ れている。本報では, 表 1 に示す実験のうち, 前報 2で実験結果が
詳細に述べられている Al シリーズ 120Gal 入力(A1-120), BL シリ 一ズ 120Gal 入力(BL-120), 240Gal 入力(BL-240), B1 シリーズ 120Gal 入力(B1-120)の 4 ケースを検討対象とする.

図 1 に, BL シリーズの実験で用いた大型せん断土槽, 地盤-杭一 構造物模型，センサー配置例を示す。土槽は，高さ $6 \mathrm{~m}$, 幅 $12 \mathrm{~m}$, 奥行き $3.5 \mathrm{~m}$ で, 29 段のフレームで構成さ扟ている，地盤は，表層 の乾燥砂層, 液状化の可能性のある飽和砂層, 下部の密な砂唩層の 3 層加らなる．杭は，直径 $16.52 \mathrm{~cm}$ ，板厚 $0.37 \mathrm{~cm}$ の鋼管杭 4 本を用 い, 杭の先端はピン支持され，頭部は基礎部に剛結されている，基 礎および上部楼造物の質量はそ扎ぞれ $2.1 \mathrm{t} ， 14.2 \mathrm{t}$ である。

振動実験 1122 で用いた入力加速度は，南関東地震を想定して作ら れた臨海波(図 2(e))の最大加速度振幅を調整した波である.実験の 間, 上部構造物及び基礎の加速度と变位, 杭の曲げ歪みと間隙水圧, 地盤及び杭の加速度が測定されている。なお，実験詳細は文献 122 に詳しい。

各実験開始前に測定されたコーン貫入値および次式 ${ }^{334)}$ を用いて 推定した標準貫入試験 $N$ 值, 相対密度 $\left(D_{r}\right)$ を表 2 に示す.

表1実験シリース

\begin{tabular}{|c|c|c|c|}
\hline シリース & 根入れ & 構造物(固有周期) & 検討対象 \\
\hline Al & なし & なし & 120Gal入力 \\
\hline $\mathrm{AL}$ & なし & あり $0.8 s)$ & \\
\hline AS & なし & あり $(0.2 s)$ & \\
\hline BS & あり & あり $(0.2 s)$ & \\
\hline BL & あり & あり $(0.8 \mathrm{~s})$ & $120,240 \mathrm{Gal}$ 入力 \\
\hline B1 & あり & なし & 120Gal入力 \\
\hline
\end{tabular}

$*$ 東京工業大学大学院理工学研究科建築学専攻 教授 $\cdot$ 工博 Prof., Dept. of Architecture and Building Engineering, Graduate School of Science and Engineering, Tokyo Institute of Technology, Dr. Eng.

** 東京工業大学大学院理工学研究科建築学尃攻 大学院生 Grentere School of Science and Engineering, Tokyo Institute of Technology General Manager, Nippon Steel Corp., Building Construction Div., Dr. Eng. 


$$
\begin{aligned}
& q_{c}=0.98 N D_{50}^{0.22} \approx 0.76 \mathrm{~N} \\
& D_{r}=21 \sqrt{\frac{98 N}{\sigma_{v}+68.6}}
\end{aligned}
$$

ここで， $q_{c}$ はコーン頯入值 $\left(\mathrm{kN} / \mathrm{m}^{2}\right) ， \sigma_{v}{ }^{\prime}$ は有効上載王 $\left(\mathrm{kN} / \mathrm{m}^{2}\right)$ を示す. 表より，A1，BL，B1 の順に密度が高くなっていることが加か。.

なお，前報2と同様に，以下の検討における杭の水平地盤反力は， 杭の実測曲げ歪みを明げモーメントに変換した後，深度方向に微分 して推定し，地盤と杭の相対変位は，両者の実測加速度記録を時間 で 2 回積分し差分をとることで推定している.

図 2 に，BL-240 深度 $2.5 \mathrm{~m}$ での相対変位，地盤反力, 地盤反力係 数と間隙水圧と入力加速度の時刻歴を示す．地盤反力係数は， 1 秒 間ごとに, 地盤反力の最大值を相対変位の最大值と杭径で除して求 め，区間中央の時刻に対応させて示している。

図 2 より, 10 秒前後から相対変位の增加之渦剩間隙水圧比の上 昇が認められ，20秒前後で地盤が完全に液状化していることが分 かる.これにともなって, 地盤反力係数は，10〜40 秒の間に $10^{4}$ 以 上から $10^{3}$ 以下へ大きく低下している. 以上のことは, 地盤反力倸 数が, 間隙水圧, 地盤と杭の相対変位に影響を受けていることを示 している。 また, 前報より, 間隙水圧や相対変位は地盤密度や入力 加速度に依存することがわかっている，以下ではこ狆らの影響の定

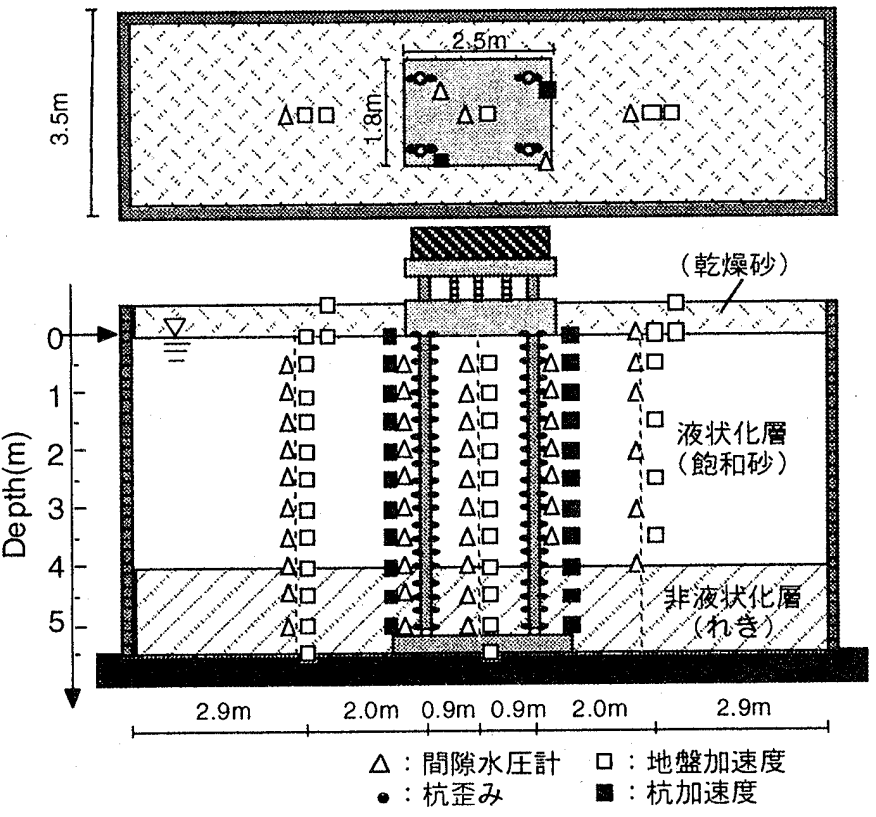

図1地盤-基礎-構造物模型

表2 地盤の物性値

\begin{tabular}{|c|c|c|c|c|c|}
\hline $\begin{array}{c}\text { 実験 } \\
\text { ID }\end{array}$ & $\begin{array}{c}\text { 深度 } \\
(\mathrm{m})\end{array}$ & $\begin{array}{c}q_{C} \\
\left(M N / \mathrm{m}^{2}\right)\end{array}$ & $N$ & $\begin{array}{c}D_{r} \\
(\%)\end{array}$ & $\begin{array}{c}k_{h 1} \\
\left(M N / \mathrm{m}^{3}\right)\end{array}$ \\
\hline \multirow{4}{*}{$\mathrm{A} 1$} & 1.0 & 1.5 & 2 & 30 & 11.7 \\
& 2.5 & 1.0 & 1 & 25 & 7.2 \\
& 4.5 & 8.0 以上 & 10 以上 & 65 以上 & 69.4 \\
\hline & 1.0 & 2.0 & 2 & 35 & 14.2 \\
& 1.5 & 2.5 & 3 & 40 & 22.0 \\
& 2.0 & 4.0 & 5 & 45 & 34.0 \\
BL & 2.5 & 4.5 & 6 & 50 & 39.8 \\
& 3.0 & 6.0 & 8 & 55 & 52.0 \\
& 3.5 & 8.0 & 10 & 65 & 69.4 \\
& 4.0 & 8.0 以上 & 10 以上 & 65 以上 & 69.4 以上 \\
& 4.5 & 8.0 以上 & 10 以上 & 65 以上 & 69.4 以上 \\
\hline \multirow{5}{*}{ B1 } & 1.0 & 2.5 & 3 & 40 & 22.3 \\
& 2.5 & 8.0 & 10 & 65 & 69.4 \\
& 4.5 & 8.0 以上 & 10 以上 & 65 以上 & 69.4 以上 \\
\hline
\end{tabular}

咟的評価を試みる。

\section{2 間腺水圧比と地盤反力係数の関係}

図 $3 に ， \mathrm{Bl}-240$ 媣度 $2.5 \mathrm{~m}$ の 0 80 秒での地盤反力係数と間隙水 圧比 Uの関係を対応する相対変位 $y$ ごとに示す．なお，相対変位 が $0.02 \mathrm{~cm}$ 以下となる区間のデー夕は，地盤反力倸数の精度が期待 できないため除いている. 図より, 地盤反力係数は, 間腺水压比が 大きいほど低下するが，同じ間隙水圧比に対して相対変位が大きい ほど小さくなる傾向があるため，地盤反力と間隙水圧の関係を一義 的に定義することが難しい．

そこで図 3 に执いて, 同程度の相対変位 $y$ ごとに, 地盤反力係数 と間隙水压比 $U$ の関係を直線回帰して $U=0$ での地盤反力係数 $k_{h}(0, y)$ を求め, この值で任意の間隙水圧比における地盤反力係数 $k_{h}(U, y)$ 在無次元化する. 図 4 に, このようにして求めた無次元化地盤反力 係数と間隙水压比の関係老全時刻歴について示す．図より，無次元 化地盤反力係数は， $(1-\ell)^{\alpha} に$ に比例 $(\alpha=0.5 \sim 1.0)$ し, 耐者の関倸が, 液 状化前後にわたって，相対変位によらず一義的に定義できる可能性 が示唆される。 Liu and Dobry 地船反力係数が有效応力に比例することを示した。上記の結果は, この遠心載荷実験結果と対応する。

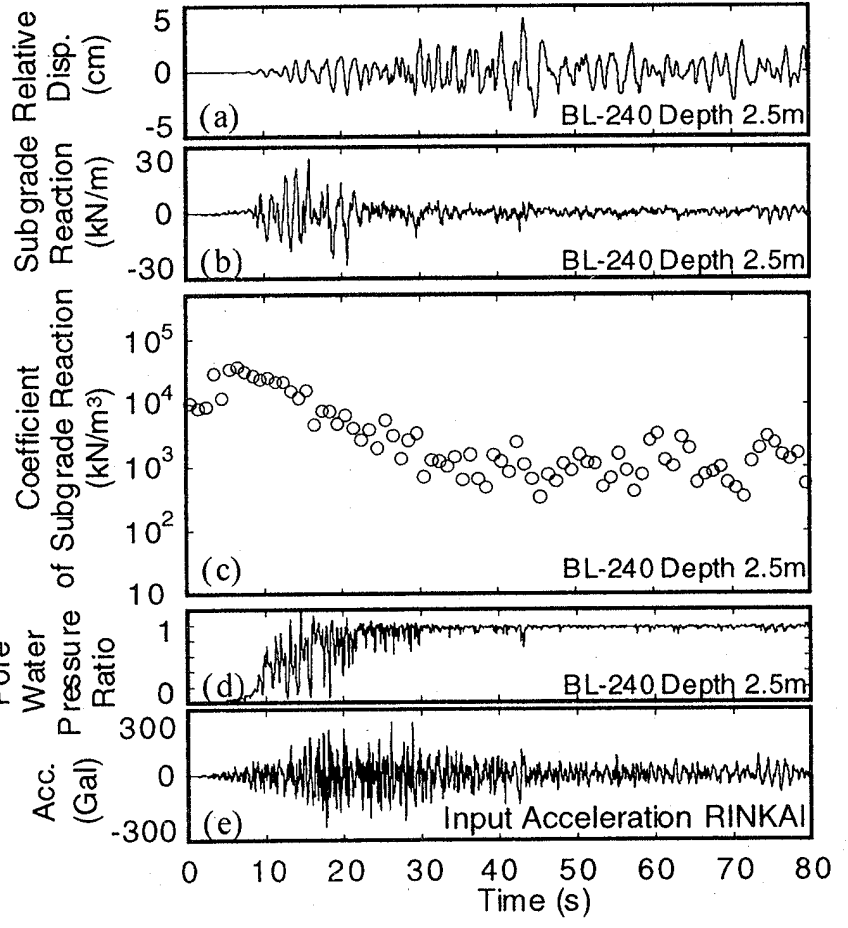

図2 入力波形とBL-240深度2.5mでの

相対変位, 地盤反力, 間隙水圧比および地盤反力係数の時刻歴

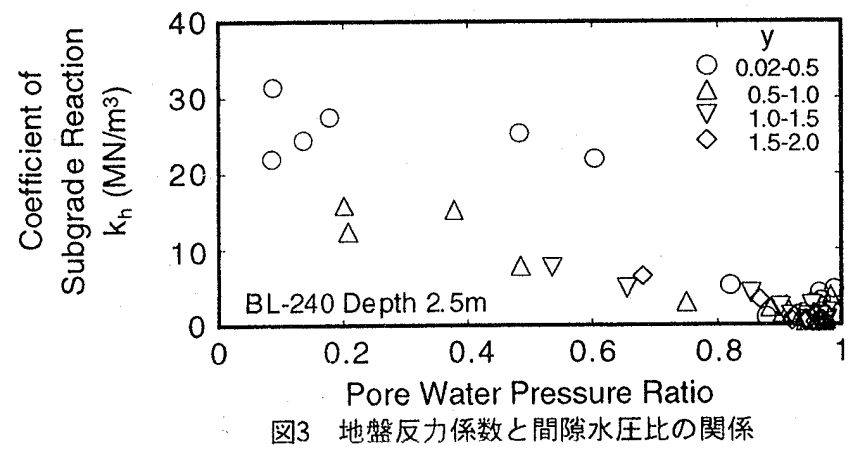




\section{3 相対変位と地盤反力係数の関係}

図 5 に，BL-240 深度 $2.5 \mathrm{~m}$ での地盤反力係数と相対変位の関係を 対応する間隙水圧比ごとに示す．地盤反力係数は，相対変位の増大 にともなって低下するが，同程度の相対変位に対して，間隙水圧比 が大きいほど小さくなる傾向を示す，そこで図 6 に，地盤反力係数 の実験值を有効応力比(1-し)で除した值と相対变位の関係を示す. 図より，有效応力比で正規化した地艋反力係数が，間隙水圧比の値 にかかわらず，相対変位の增加にともなって低下する傾向が認めら れ，両者の関倸が一義的に評価できることがわかる。

\section{4 地盤密度と地盤反力係数の関係}

図 7 は，地盤密度の異なる 3 ケースの実験(A1-120，BL-120，B1$120)$ の深度 $2.5 \mathrm{~m}$ の地盤反力係数と相対変位の関係を示している. 地盤密度が低いほど，同じ相対変位に対する地盤反力係数が小さく なっていることがわかる，そこで各実験結果から，相対変位と間腙 水圧比が同程度の時の地盤反力係数之各実験前に測定された対応深 度のコーン貫入抵抗値の関係を求め, 図 8 に示す. 図より，地盤反 力係数は，相対变位亡間隙水圧比が同じであ扎ば，コーン貫入抵抗 値にはほ比例して增加する傾向を示すことがわかる.

\section{3. 地盤反力変位関係のモデル化}

前章の考察にもとづき, 既往の推定式を改善した液状化過程での 地盤反力変位関係の推定モデルを提案する.

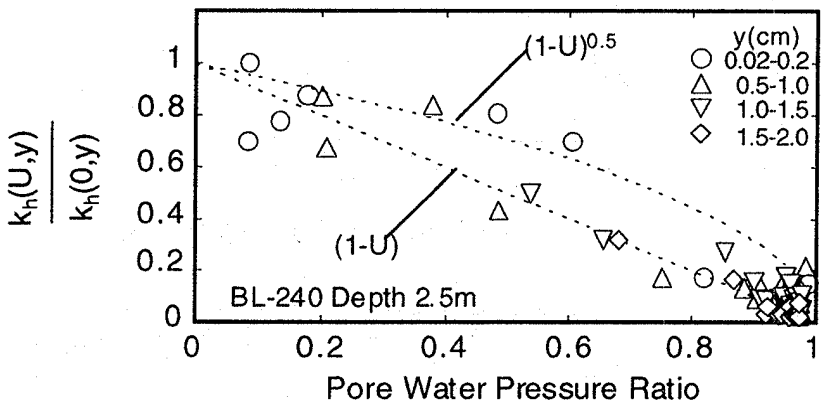

図4＼cjkstart無次元化した地盤反力係数と間隙水圧比の関係
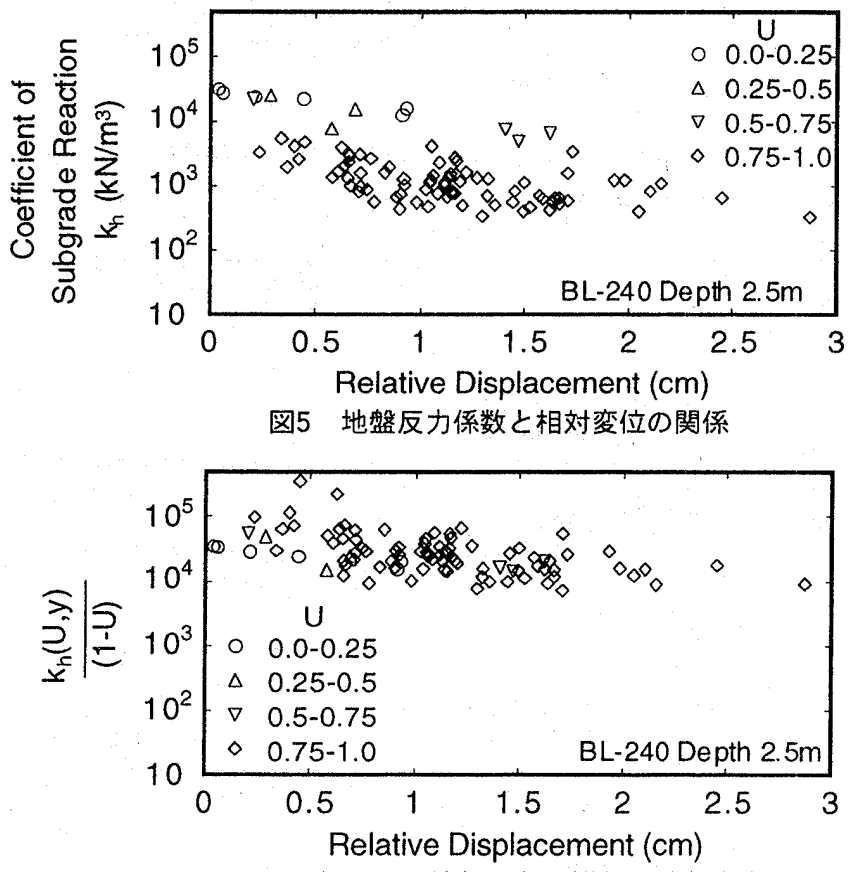

図6 正規化した地盤反力係数と相対変位の関係

\section{1 既往の地盤反力変位関係}

建築基礎棈造設計指針 "にたおいて，杭の水平地盤反力 $(p)$ と杭と地 盤の相対変位 $(y)$ の関係は，次式で与えられる。

$$
p=k_{h} B y
$$

ここに， $B$ は杭径， $k_{h}$ は地盤反力係数を表す，液状化にともなう間 隙水圧の上昇上変位の増大の影響を考虑するため, 建築基礎構造設 計指針では地盤反力係数を次式で表す。

$$
k_{h t}=\beta k_{h 1}\left(y / y_{1}\right)^{-0.5}
$$

ここで， $y_{1}$ は基準相対変位 $\left(y_{1}=1 \mathrm{~cm}\right) ， k_{b 1}$ は基隻地盤反力係数， $\beta$ は 液状化による $k_{h}$ の低減係数を表し， $y=1 \mathrm{~cm}$ を代入すると $k_{h}=\beta k_{h 1}$ と なる。なお， $k_{h}$ は次式で与えら打る。

$$
\begin{aligned}
& k_{h 1}=80 E_{00} B_{0}^{-0.75} \\
& E_{0}=0.7 \mathrm{~N}
\end{aligned}
$$

ここで， $E_{i}$ は変形係数 $\left(\mathrm{MN} / \mathrm{m}^{2}\right) ， B_{i}$ は $1 \mathrm{~cm}$ に対して無次元化した 杭幅, $N$ は標準資入苚験 $\mathrm{N}$ 値である.

図 4 の考察にもとづき， $\beta$ を間隙水庄比(U)を用いた関数で表し， $\beta=(1-U)^{\alpha}$ とする．(4)式を(3)式に代入して次式を得る。

$$
p=k_{h 1}\left(y / y_{1}\right)^{-0.5}(1-U)^{\alpha} B y
$$

(4)式において，y，Uは実験値から， $k_{b 1}$ を実測コーン貫入抵抗値 から(1)，(5)，(6)式より求め(表 2), さらに $\alpha=1.0$ として, BL-240 深 度 $2.5 \mathrm{~m}$ の地盤反力係数を推定し, 図 9 に実験値( O印)と比較して 示す(×印). 図より, 既往モデルより推定した地盤反力係数は, 実

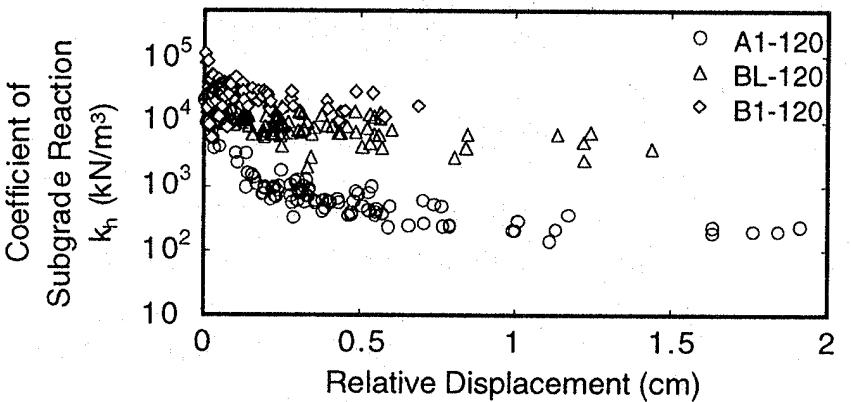

図7異なる地盤密度での地盤反力係数と相対変位の関係

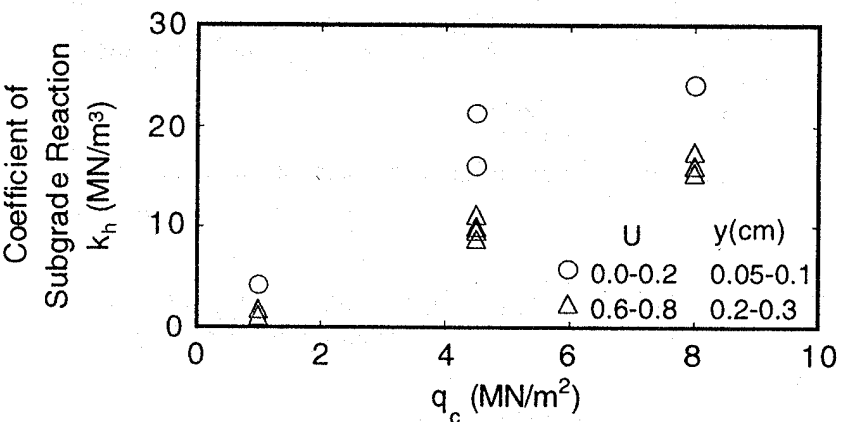

図8 コーン貫入值と地盤反力係数の関係

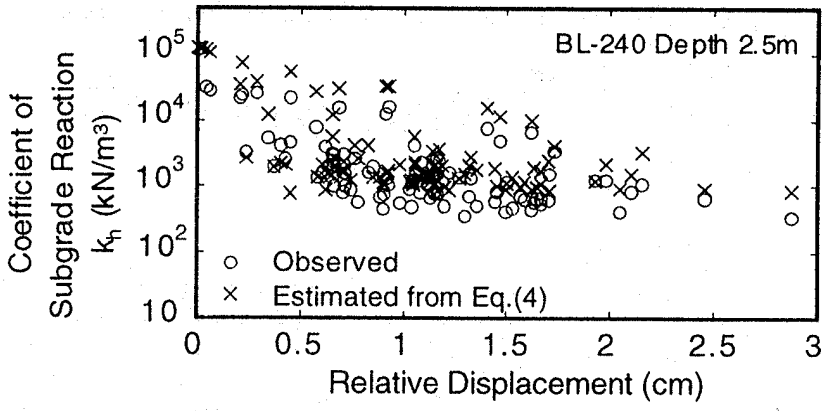

図9 実験值と建築基礎設計指針による推定値の比較 
測地盤反力係数より大きい值をとる.これは，(4)式で $k_{h}=\beta k_{h 1}$ とな る基準相対変位 $y_{1}$ が，杭径 $B$ に関わらず $1.0 \mathrm{~cm}$ であることから， 実験のような小さな杭径に対して, 対応する杭周辺のひずみレベル $\left(y_{1} / B\right.$ に比例)が大きくなるためと考えられる。

\section{2 提案モテル}

本報告では既往モデルの問題点を解消するために，地盤反力係数 を次式でモデル化する.

$$
k_{h}=k_{h 1} \frac{2}{1+\left|y / y_{i}\right|}(1-U)^{k}
$$

(8)式に, $y=0, U=0$ を代入すると $k_{h}=2 k_{h 1}$ となり,$y=y_{1}$ を代入すると $k_{i l}=k_{h l}(1-U)^{\alpha}$ 亡なる. (3), (8)式より, 地盤反力变位関係は次式で与 えら扎る.

$$
p=\frac{2 k_{i 1}}{1+\left|y / y_{1}\right|}(1-U)^{\alpha} B y
$$

(9)式中の $y$ を無限大にすると, 地盤反力最大值 $\left(p_{\text {max }}\right)$ は次式となる.

$$
p_{\text {max }}=2 k_{h 1}(1-U)^{\alpha} B y_{1}
$$

(8)式において， $k_{h 1}$ および $\alpha$ は既往モデルと同様に定め， $y_{1}$ は，前 節の考察と既往の文献 7$)$ )を参考に, 杭径の約 $1 \%$ (杭径 $16.52 \mathrm{~cm}$ で $\left.y_{1}=0.2 \mathrm{~cm}\right)$ とし $\tau$ BL-240 深度 $2.5 \mathrm{~m}$ の地盤反力係数を推定し, 図 10 に実験値と比較して示す，推定地盤反力係数は, 実験結果の傾向を

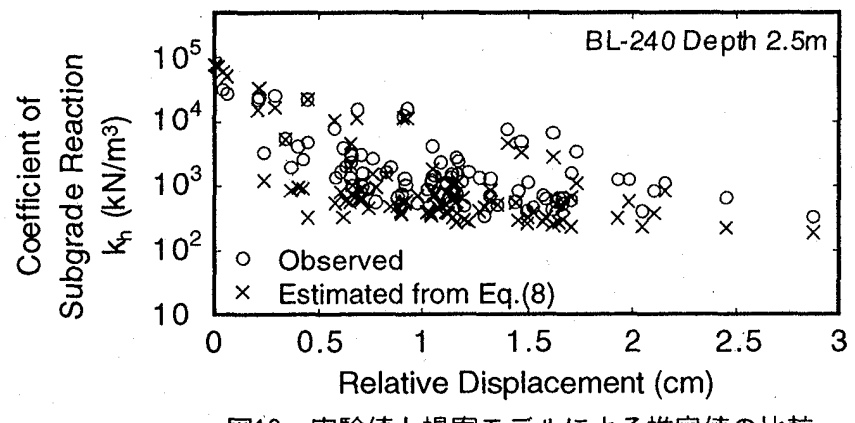

図10 実験値と提案モデルによる推定値の比較

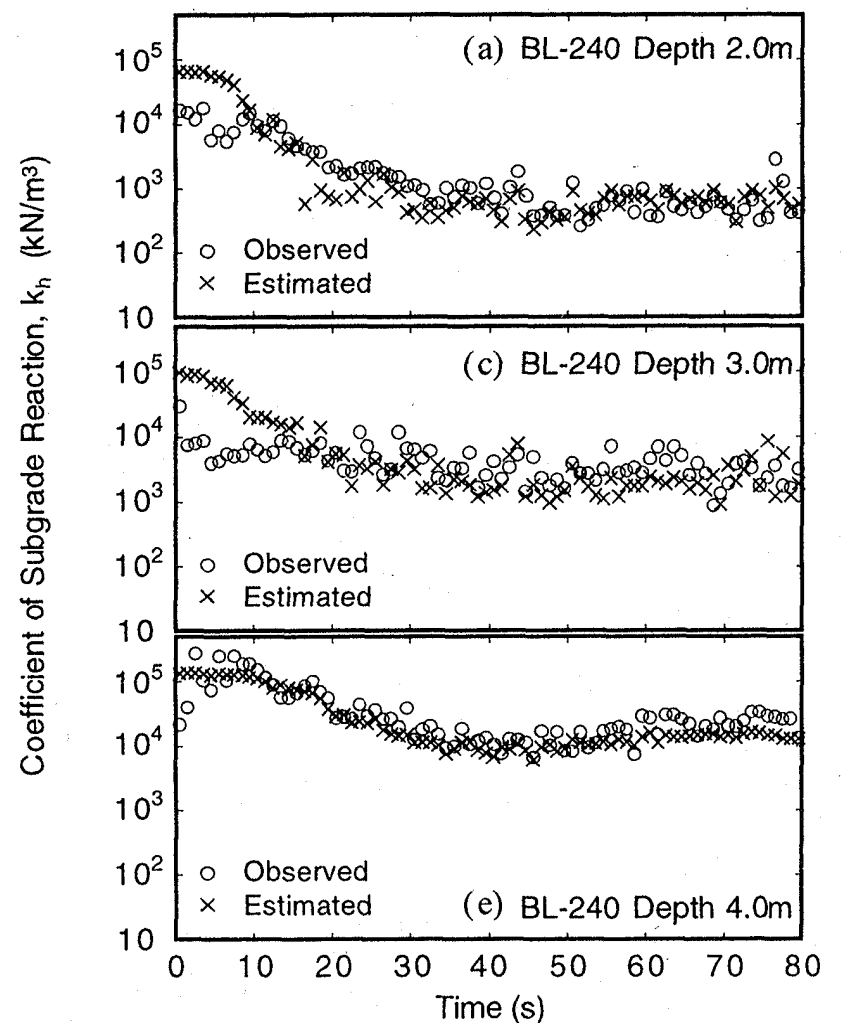

よくとらえている。

(7), (9)式の違いを確認するため, 両式から無次元化変位 $\left(y / y_{1}\right)$ に

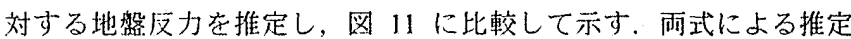
地盤反力は， $y / y_{1}<3$ では大きな違いは見られない。したがって，(7) 式(既往モデル)でも $y_{1}=0.01 B$ とすれば，実験值と整合性がとれるも のと考えられる。しかし，無次元化変位がさらに大きくなると，(7) 式による推定地盤反力に比べ，(9)式(提案モデル)による推定地盤反 力はやや低い値となり；(10)式の地盤反力最大値に収束することが わかる.このため, 提桑モデルでは, (9)式を(10)式で除すことで, 無次元化した地盤反力变位関係の骨格曲線を次式で定義できる.

$$
\frac{p}{p_{\max }}=\frac{y / y_{i}}{1+\left|y / s_{i}\right|}
$$

(11)式により，閴隙水圧が変化する際の地盤反力変位関係の履歴曲 線の設定が容易になる。

履歴曲線には，スケーリングハラメー夕を導入することで減衰を 調節できるように修正した Masing 則 》を適用する，履歴曲線の最 大減衰は $20 \%$ とする。なお，(7)式では，地盤反力の最大值が定義 できないため, 以上のような無次元化骨格曲線と減衰を調節した履 歴曲線の設定が難しい。

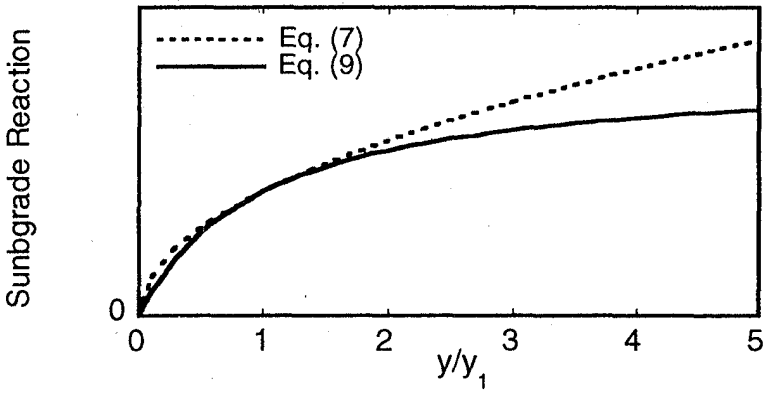

図11 推定地盤反力と変位の関係

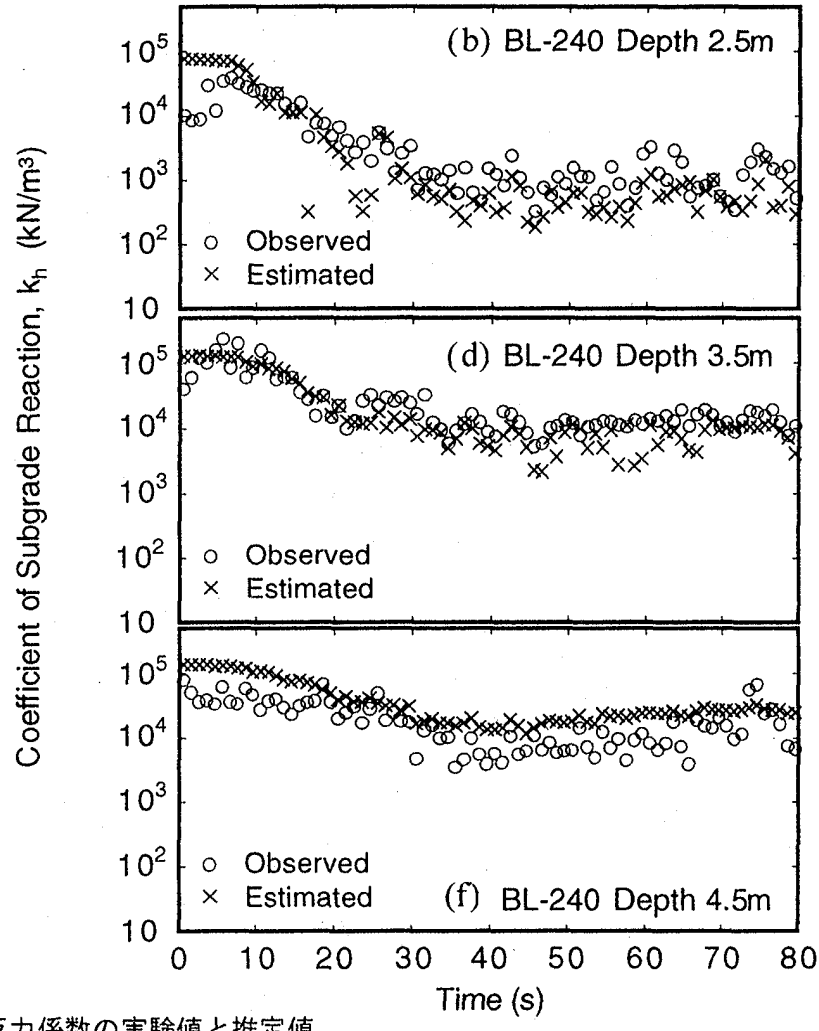




\section{4. 提案モテルの妥当性の検討}

実験結果のうち相対変位と間隙水圧比が既知として，地盤反力係 数および地盤反力変位関係の時刻歴を推定し, 実験結果と比較する.

\subsection{BL シリーズでの実験値と推定値の比較}

图 12 に，BL-240 深度 $2.0 \sim 4.5 \mathrm{~m}$ の推定地盤反力係数の時刻歴を 実験值と比較して示す．地盤反力係数の実験值は，地盤の間隙水圧 が上昇する 10〜30 秒にかけて，地表に近いほど小さくなる煩向が ある，推定值は，以上の傾问をとらえている.

図 13，14に，BL-240 樑度 $2.0 〜 4.5 \mathrm{~m}$ の推定した地盤反力变位関 係を夷験結果と比較して示す。図より，深度 $2.0 \mathrm{~m} ， 2.5 \mathrm{~m}$ の間腺水 圧上昇過程(0〜20 秒)に抒いて(図 13(a)，(d)), 変位がある倌を越え ると実測地盤反力が急激に大きくなるため，地盤反力変位関係が逆 $\mathrm{S}$ 字型になる傾向を示す.しかし，液状化後(20～80 秒)では(図 13(b), (c)，(e)，(f)), 地盤反力が急激に小さくなる結果, 地盤反力変位関 係が逆 $\mathrm{S}$ 字型になる傾向は消失する. また，その他の深度におい
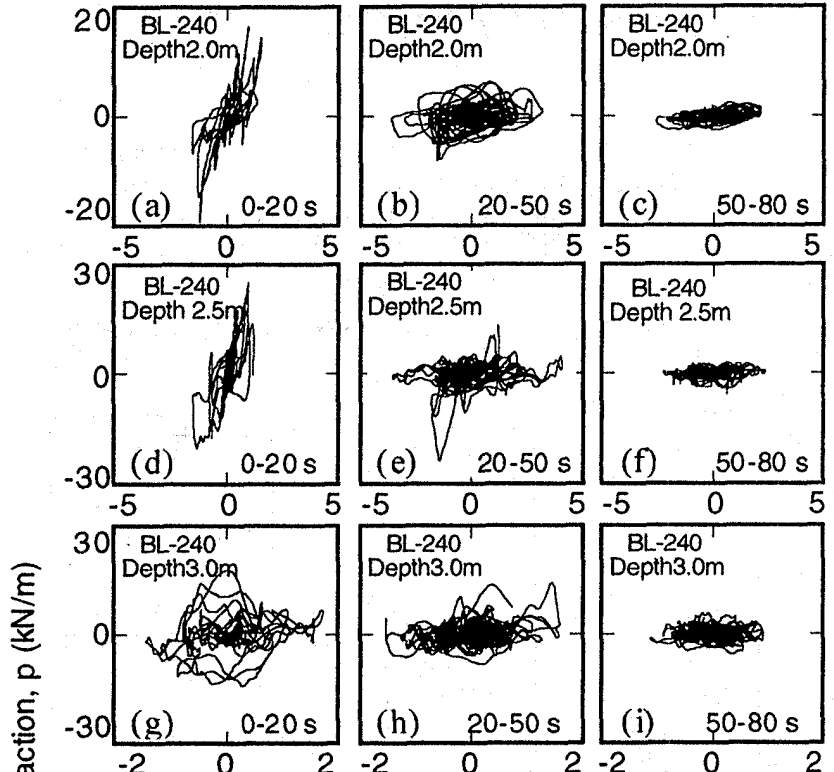

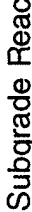
$\begin{array}{llll}-2 & 0 & 2 & -2\end{array}$

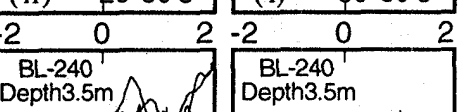

(3)

BL-240 Depth3.5my

아

-30 (i) $\quad 0.20 \mathrm{~s}$
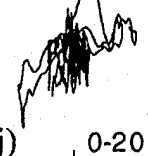

(1)
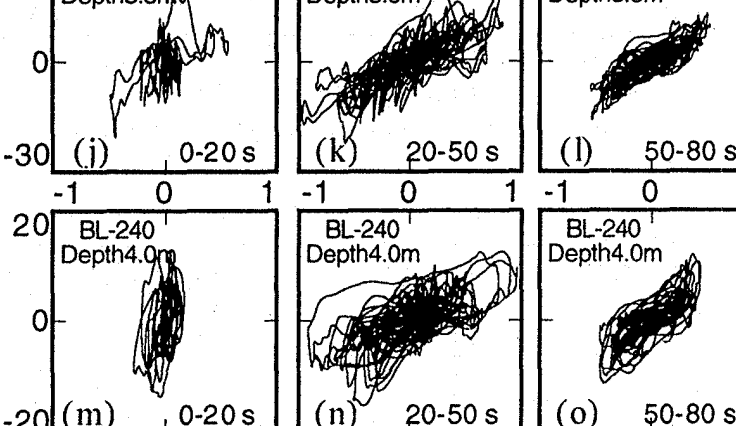

(l) $50-80 \mathrm{~s}$

$-20\lfloor(m)$
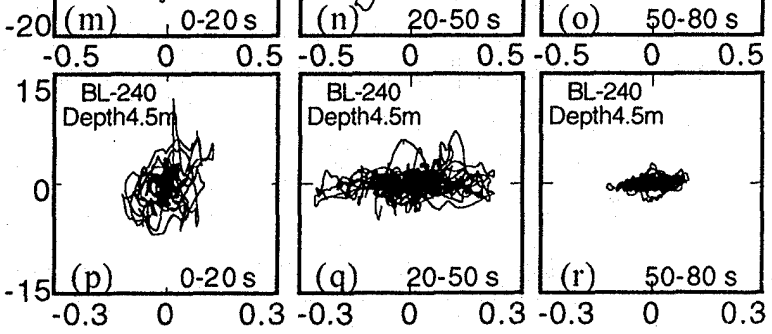

Relative Displacement $(\mathrm{cm})$

図13 BL-240の実測地盤反力変位関係

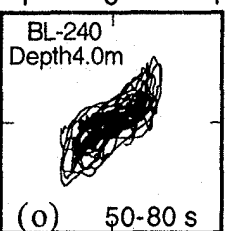

ても, 間陌水圧が上昇した 20 秒後においては, 絽り返し履歴によ り地船反力変位関係の傾きが徐々に小さくなる. 図 14 より, 推定 さ扎た地盤反力変位関係は, 以上のような実験結果の傾向をよく再 現している.

大カレベルが異なる場合でも，モデル化が妥当であるか確認する ため, 図 $15 に, B L-120$ 深度 $2.5 \mathrm{~m}, 4.5 \mathrm{~m}$ の推定地船反力係数の時 刻歷を実験值と比較して示す。いずれの深度でも, 入力が大きい BL-240 (図 12) と比較して, 実測地盤反力保数の低下が抑えられて いる. 推定地盤反力係数はその傾向を捉えている.

図 $16 ， 17$ に，BL- 120 深度 $2.5 \mathrm{~m} ， 4.5 \mathrm{~m}$ の推定した地盤反力変位 関係を実験結果と比較して示す, 図より, 深度 $2.5 \mathrm{~m}$ の実測地盤反 力変位関係(図 16(a)，(b)，(c))は，逆 $\mathrm{S}$ 字型になる傾向が見られ， 液状化後も同様の傾向を示す. 一方, 入力の大きい BL-240 深度 $2.5 \mathrm{~m}$ の実測地盤反力変位関係(図 13(d)，(e)，(f))は，液状化後に逆 S 字 型の傾向が消失し，傾きが小さくなる，深度 $4.5 \mathrm{~m}$ の実測地盤反力
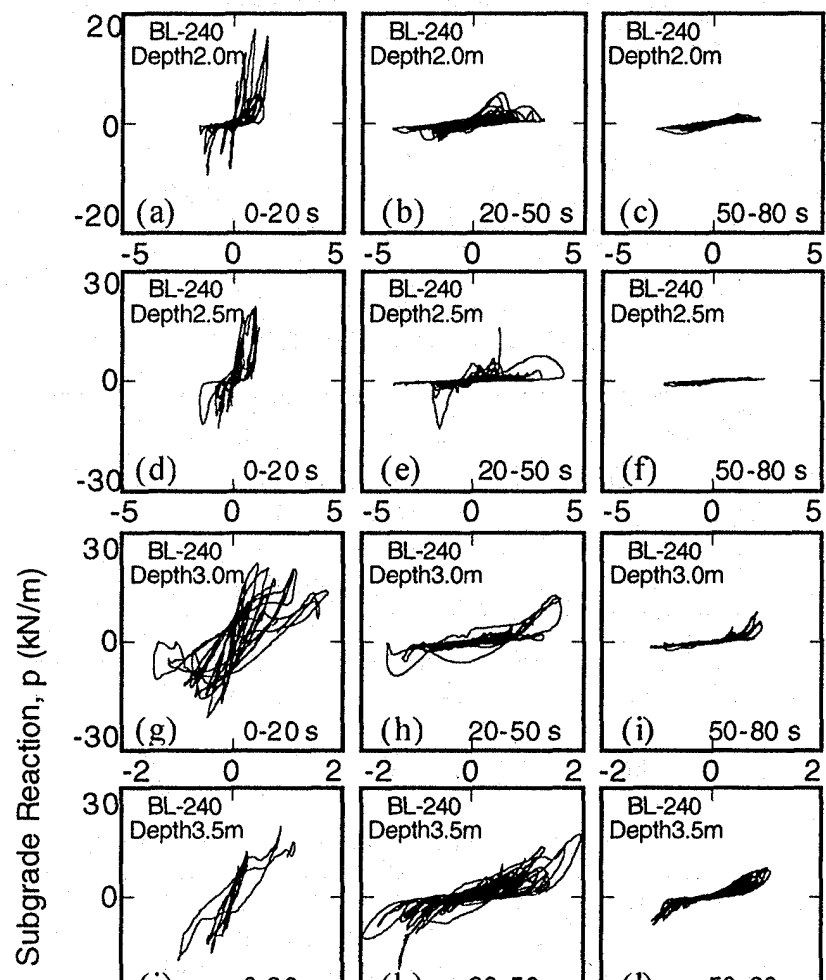

BL-240

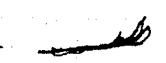

$-30(\mathrm{~g}) \quad 0-20 \mathrm{~s}$

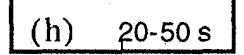

(i) $50-80 \mathrm{~s}$
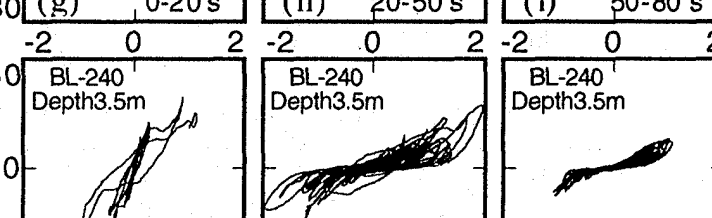

-30 (i) $\quad 0-20 \mathrm{~s}$
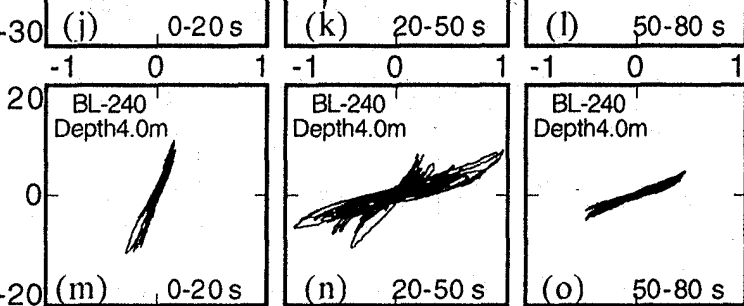

$\begin{array}{lll}-1 & 0 & 1\end{array}$
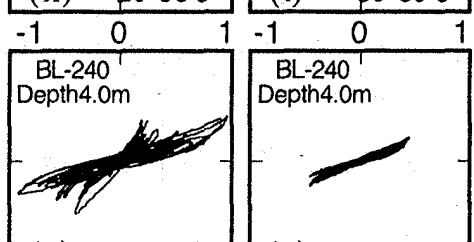

BL-240 Depth4.0m

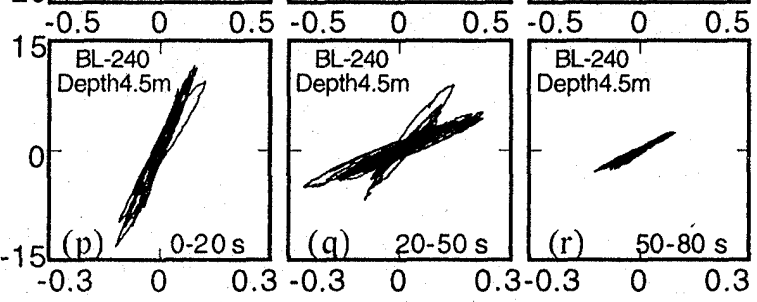

Relative Displacement (cm)

図14 BL-2400推定地盤反力変位関係 
変位関保(図 16(d), (e), (f))も, 間隙水圧上昇の前後での傾きの低 下がほとんビ見られない。一方，入力の大きい BL240 深度 $4.5 \mathrm{~m}$ の 実測地盤反力変位関倸(図 13(p), (q), (r)) の傾きは, 間隙水圧上咞 後に低下している。図 17 より, 推定地盤反力変位関係は, 以上の 傾向をよく捉えている.

\section{2 異なるシリースでの実験値と推定値の比較}

図 18 に，地盤密度が異なる $\mathrm{A} 1-120, \mathrm{~B} 1-120$ 深度 $2.5 \mathrm{~m}$ での推定

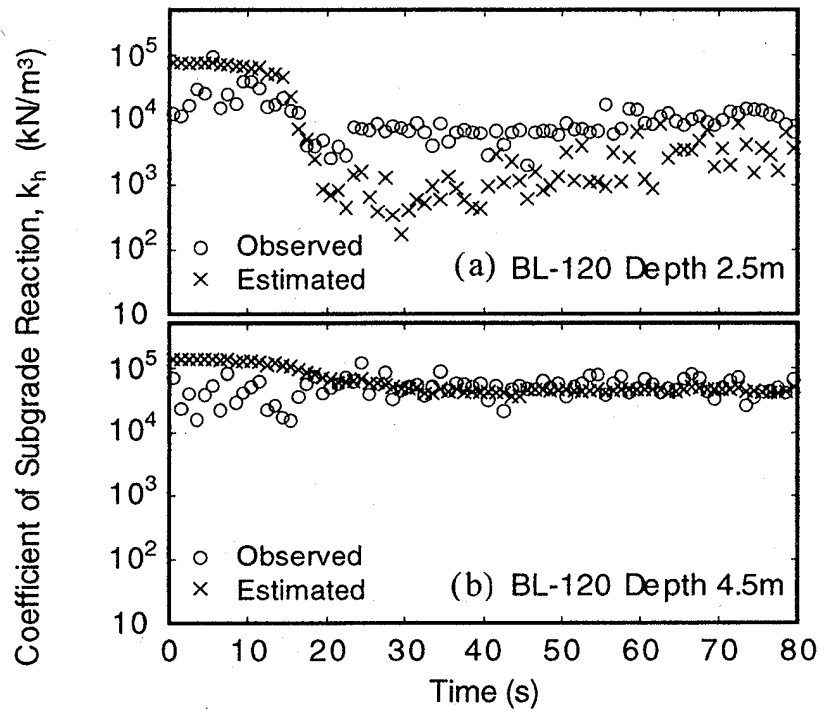

図15 BL-120での地盤反力係数の実験值と推定值

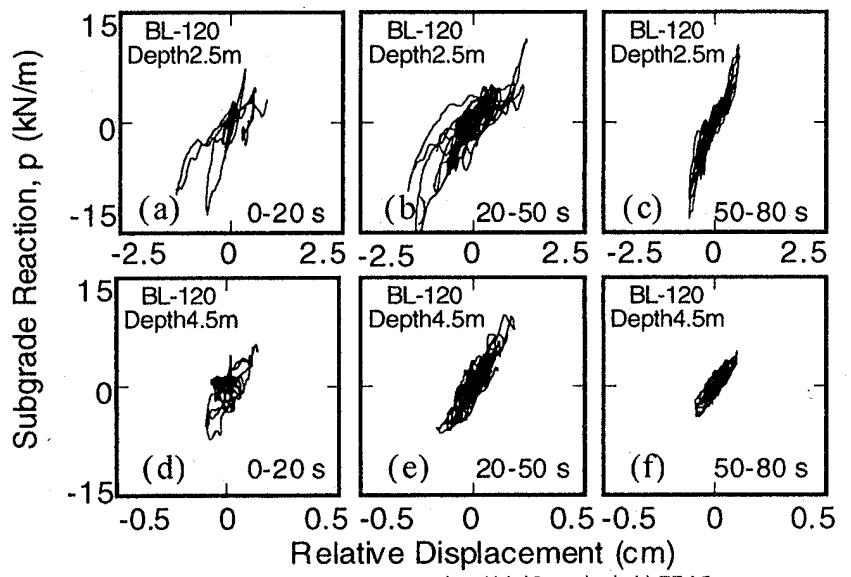

図16 BL-120の実測地盤反力変位関係

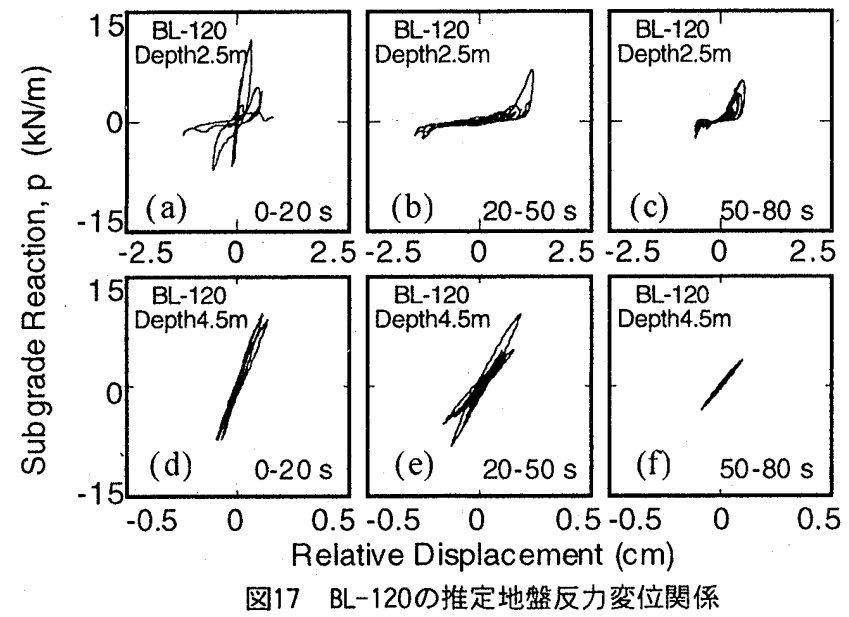

地般反力係数の時刻厢を実験値と比較して示す. 実測地盤反力係数 は，地盤密度が低いほざ小さく，また液状化後に大きく低下する傾 向がある. 推定地瞥反力係数は以上の傾向をよ゙くとらえている。

図 19,20に，A1-120，B1-120 深度 $2.5 \mathrm{~m}$ の推定した地盤反力変 位関係を実験結果と比較して示す.図より,BL-120の同深度(図 16(a), (b), (c)) と比較して, 地盤密度が低いと(図 19(a), (b), (c))), 変位が 大きくなっても地盤反力はほとんど生じず, 実測地盤反力変位関倸

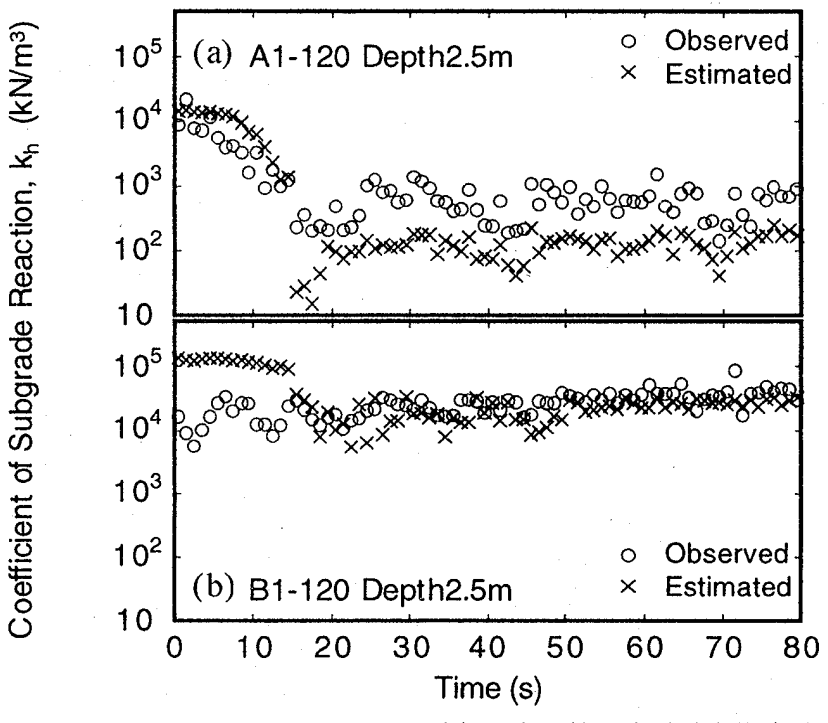

図18 A1-120,B1-120での地盤反力係数の実験値と推定値

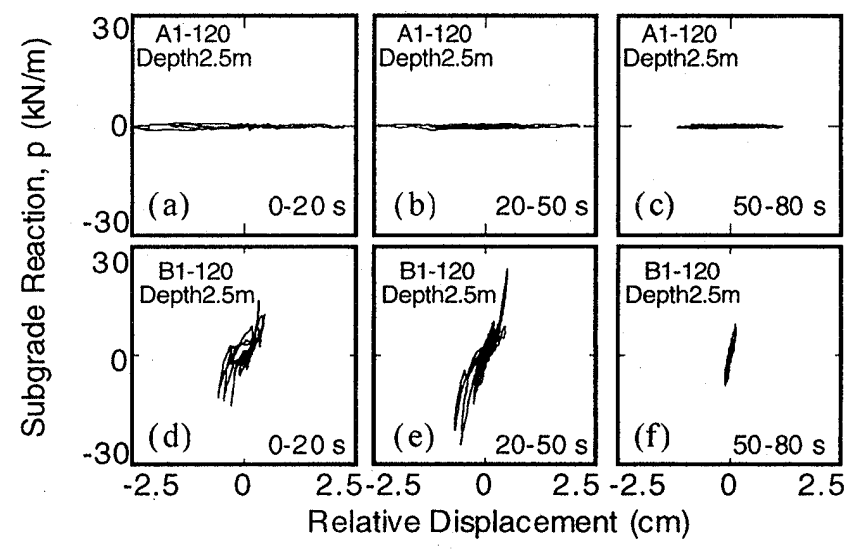

図19 A1-120、B1-120の実測地盤反力変位関係

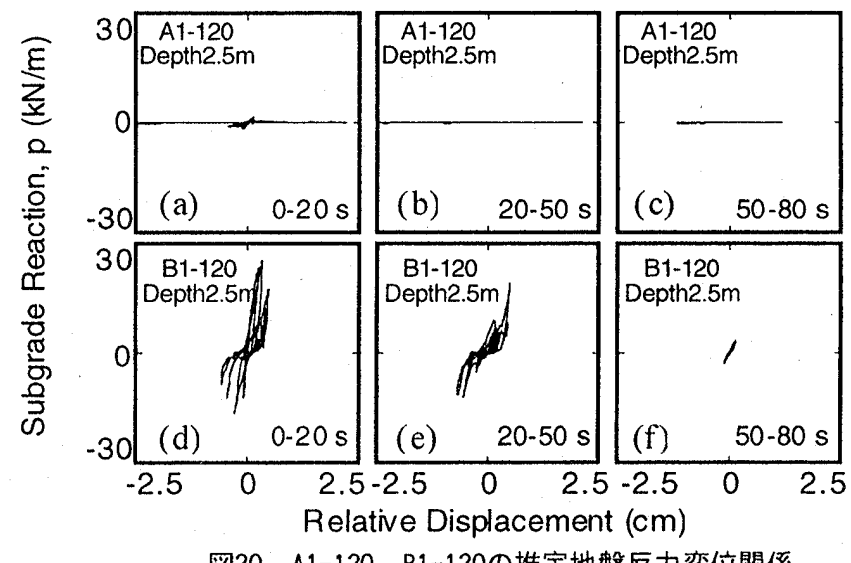

図20 A1-120，B1-1200推定地盤反力変位関係 
の傾きが極めて小さい，一方，地盤密度が高いと(図 19(d), (e), (f)), わずかな変位で地盤反力が急激に大きくなり，実測地盤反力変位関 係が逆 S 字型を示し，その傾きが大きくなる．図20より，推定さ 扎た地盤反力変位関係は以上の傾向をよく再現している.

\section{5. まとめ}

地盤-杭-棰造物系に対する大型振動台を用いた液状化実験結果に もとづいて，杭の水平地盤反力係数および地盤反力变位関係を推定 するモデルを提案した．モデルの妥当性を検討するために，実験に おけるこれらの時刻歴を推定し，実験結果と比較した結果，以下の 結論を得た。

（1）基礎構造設計指針にもとづいて液状化過程の地盤反力係数を 推定する際，基準変位を $y_{1}=1 \mathrm{~cm}$ とすると実駼結果を過大評価 する。これ在改善するためには， $y_{1}=0.01 B$ とすることが有効 と考元ら㧈る。

(2) 提案モデルによる推定地盤反力係数および推定地盤反力の时 刻歴は，深度，入カレベル，地盤密度にかかわらず，実験結 果と同様の傾向を示す．以上より，提案モデルは，液状化過 程での地盤反力係数および地盤反力変位関係を推定するうえ
で有望である.

的辞

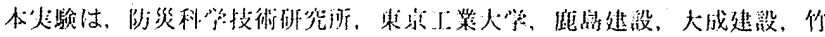

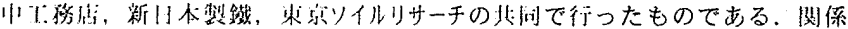
热に乵して感稚します。

\section{参考文献}

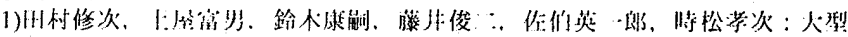

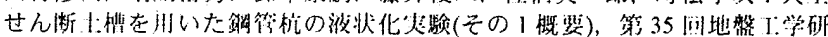
究発食会。pp.1907-1908，2000.6

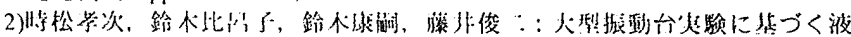

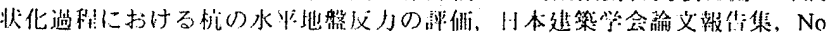
553, pp.57-64,2002.3

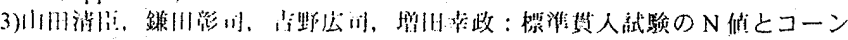

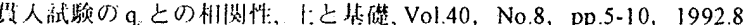

4)Meyerh of, G. G. : Discussion, Proceedings Fourth ICSMFE, Vol.3, pp.110, 1957.8 5)Liu, L. and Dobry, R. : Effect of liquefaction on lateral response of piles by centrifuge model tests, National Center for Earthquake Engineering Research (NCEER) Bulletin, Vol.9, No.1, pp.7-11, 1995.1

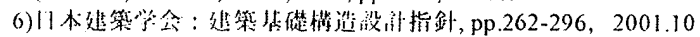

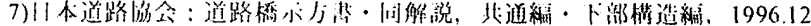

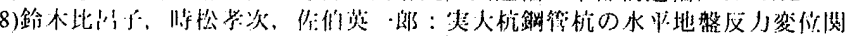

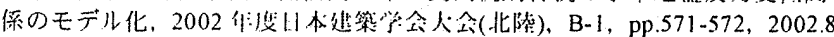

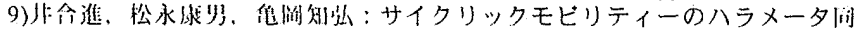

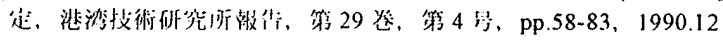

（2002年 3 月 10 日原稿受理，2002年 7 月 1 日採用決定） 